\title{
Transcriptome analysis of granulosa cells after conventional vs long FSH-induced superstimulation in cattle
}

\author{
F. C. F. Dias ${ }^{1}$, M. I. R. Khan ${ }^{1,3}$, M. A. Sirard ${ }^{2}$, G. P. Adams ${ }^{1}$ and J. Singh ${ }^{1 *}$ (D)
}

\begin{abstract}
Background: Prolongation of superstimulatory treatment appears to be associated with a greater superovulatory response and with greater oocyte maturation in cattle. A genome-wide bovine oligo-microarray was used to compare the gene expression of granulosa cells collected from ovarian follicles after differing durations of the growing phase induced by exogenous FSH treatment. Cows were given a conventional (4-day) or long (7-day) superstimulatory treatment ( $25 \mathrm{mg} \mathrm{FSH}$ im at 12 -h intervals; $n=6$ per group), followed by prostaglandin treatment with last FSH and LH treatment $24 \mathrm{~h}$ later. Granulosa cells were harvested $24 \mathrm{~h}$ after LH treatment.

Results: The expression of 416 genes was down-regulated and 615 genes was up-regulated in the long FSH group compared to the conventional FSH group. Quantification by RT-PCR of 7 genes (NTS, PTGS2, PTX3, RGS2, INHBA, CCND2 and $\angle R P 8)$ supported the microarrays data. Multigene bioinformatic analysis indicates that markers of fertility and follicle maturity were up-regulated in the long FSH group.

Conclusion: Using the large gene expression dataset generated by the genomic analysis and our previous associated with the growth phase and gene expression changes post $\mathrm{LH}$, we can conclude that a prolonged FSH-induced growing phase is associated with transcriptomic characteristics of greater follicular maturity and may therefore be more appropriate for optimizing the superovulatory response and developmental competence of oocytes in cattle.
\end{abstract}

Keywords: Cattle, Follicular waves, Follicle growth, Granulosa cells, Gene expression, Genomic analysis, Microarrays, Ovary, Superstimulation

\section{Background}

An increase in peripheral FSH concentrations precedes emergence of each new follicular wave in cattle [1]. A follicular wave is characterized by the emergence of a growing cohort of FSH-responsive follicles, one of which is selected for continued growth (dominant follicle) while remaining subordinates follicles regress [2]. The majority of estrous cycles in cattle are composed of 2 or 3 follicular waves, the last of which culminates in ovulation of the dominant follicle. Major differences between 2 - vs 3-wave cycles are a significantly shorter interovulatory interval (19 vs 23 days, respectively), a longer

\footnotetext{
* Correspondence: jaswant.singh@usask.ca

'Department of Veterinary Biomedical Sciences, Western College of Veterinary Medicine, University of Saskatchewan, 52 Campus Drive, Saskatoon, SK S7N 5B4, Canada

Full list of author information is available at the end of the article
}

growing phase of the dominant follicle of the first wave ( 8 vs 7 days, respectively) and a longer growing phase of the final (ovulatory) wave ( 9 vs 6 days, respectively) [3]. During a 2-wave estrous cycle, the ovulatory follicle grows for 6 days under a high-progesterone environment, while that of a 3-wave cycle grows for only 3 days under a high-progesterone environment [4]. Thereafter, circulating progesterone concentrations are low for both 2 - and 3-wave cycles, for approximately 3 days following luteolysis [4].

The period of growth and maximal size of the dominant follicle are inversely related to the circulating concentration of progesterone [5]. Dominant follicles maintained under a low-progesterone environment for extended periods become oversized, persistent follicles [5] containing an oocyte of decreased developmental competence [6-9]. However, the effect of different 
durations of elevated progesterone exposure during the growing phase of the ovulatory follicle (analogous to 2- or 3-waves cycle) is contradictory [10-13]. In more recent studies, extending the period of progesterone exposure during the growing and early-static phases of the ovulatory follicle by 3 days did not affect oocyte competence of the dominant follicle [14] or that of superstimulated follicles [15], but was associated with a greater superovulatory response $[15,16]$. In addition, a longer growing phase of the ovulatory follicle during superstimulation was associated with greater nuclear and cytoplasmic maturation of oocytes [17].

During folliculogenesis, somatic cells and germ cells interact through complex paracrine signalling via heterologous gap junctions to coordinate nuclear and cytoplasmic maturation of the oocyte [18]. Granulosa cell signalling affects energy uptake by the oocyte $[19,20]$, oocyte growth and development [21], and transcriptomic activity of the oocyte [22]. Granulosa cell analysis is therefore a valuable method of assessing follicular and oocyte health status. The effect of ovarian superstimulation on bovine granulosa cells has been the focus of recent studies (reviewed in [23]), and results revealed that multiple follicles growing during a standard 4-day superstimulation protocol were not as mature as a single dominant follicle from a natural cycle [24]. Based on the findings that prolongation of superstimulatory treatment appears to be associated with a greater superovulatory response in cattle $[25,26]$, the influence of prolonged FSH treatment on granulosa cell function, and the corresponding effect on the contained oocyte, is of interest in guiding our understanding of granulosa-oocyte health. In this context, it becomes very interesting to study the effect of extending the superstimulation protocol by 3 days on the global gene expression of follicular cells.

Therefore, the objective of the study was to compare the transcriptomic profile of granulosa cells from ovarian follicles exposed to a short duration (conventional 4-day treatment) vs long duration (7-day treatment) of FSHstimulated growth. Our hypothesis is that more follicles will advance in differentiation and this will improve LH responsiveness.

\section{Methods}

\section{Animals and treatments}

Twelve mature Hereford cross-bred beef cows, weighing 515 to $795 \mathrm{~kg}$, and maintained in outdoor pens, were used. Procedures were conducted in accordance with the guidelines of the Canadian Council on Animal Care and were approved by University of Saskatchewan Protocol Review Committee.

A luteolytic dose of prostaglandin $\mathrm{F}_{2 \alpha}\left(\mathrm{PGF}_{2 \alpha} ; 500 \mu \mathrm{g}\right.$ cloprostenol im; Estrumate, Schering-Plough Animal Health, Pointe-Claire, PQ, Canada) was given twice,
14 days apart to synchronize estrus. The ovaries were examined by transrectal ultrasonography every $24 \mathrm{~h}$ after the second $\mathrm{PGF}_{2 \alpha}$ treatment to detect ovulation. Five to 8 days after ovulation, follicles $\geq 5 \mathrm{~mm}$ in diameter were ablated by transvaginal ultrasound-guided follicle aspiration to synchronize the emergence of a new follicular wave 1 day later [27]. An intravaginal progesteronereleasing device (CIDR-B, $1.38 \mathrm{~g}$ progesterone, Pfizer Canada Inc., Kirkland QC, Canada) was placed in the vagina immediately after follicle ablation.

The cows were allocated randomly to two groups ( $n=6$ /group) and given either a 4-day (conventional FSH) or 7-day (long FSH) superstimulatory protocol (Fig. 1). Starting on the day of wave emergence (Day 0), i.e., 1 day after follicle ablation, cows in the conventional FSH group were given 8 im treatments of FSH (Folltropin-V; Bioniche Animal Health, Belleville ON, Canada; each equivalent to $25 \mathrm{mg}$ of NIH-FSH-P1) at 12-h intervals over 4 days. Cows in the long FSH group were given $14 \mathrm{im}$ treatments of FSH over $7 \mathrm{~d}$ (each dose equivalent to $25 \mathrm{mg}$ of NIH-FSHP1). Cows in the conventional FSH group were given two luteolytic doses of $\mathrm{PGF}_{2 \alpha}$ im $12 \mathrm{~h}$ apart on Day 3, whereas the cows in the long FSH group were given the same $\mathrm{PGF}_{2 \alpha}$ treatment on Day 6. The CIDR was removed concurrent with the second prostaglandin treatment. Cows were treated with $25 \mathrm{mg} \mathrm{LH}$ im (Lutropin-V, Bioniche Animal Health) $24 \mathrm{~h}$ after CIDR removal. Cows were ovariectomized $24 \mathrm{~h}$ after $\mathrm{LH}$ treatment.

\section{Tissue collection}

Bilateral ovariectomy was performed by colpotomy, as described [28]. Briefly, caudal epidural anesthesia was induced with $2 \%$ lidocaine $\mathrm{HCl}$ and $0.01 \mathrm{mg} / \mathrm{ml}$ of epinephrine (Bimeda-MTC Animal Health Inc., Lavaltrie, QC, Canada). The perineum was washed using an iodine-based detergent and solution. A small incision was made in the dorso-lateral aspect of the vaginal fornix using a scalpel blade; the peritoneum was manually punctured to allow access to the peritoneal cavity. The mesovarium was compressed with a lidocaine/epinephrine-soaked gauze and a plastic clip was placed across the ovarian pedicle to compress the ovarian vessels. The chain of an ecraseur (19" Chassaignac; German-made; Jorgensen Lab, Loveland, Colorado, USA) was looped around the ovary and slowly tightened until the ovarian pedicle was severed. The ovaries were placed in a polyethylene bag on ice and transported to the laboratory within $5 \mathrm{~min}$ after collection. After ovariectomy number of follicles $\geq 5 \mathrm{~mm}$ was counted and the three largest follicles (in the pair of ovaries) were selected. The goal was to include both antral and mural granulosa cells in the sample for analysis. Follicular contents were aspirated using a 20 gauge needle and a syringe, and the follicle was flushed 3 times with Dulbecco's phosphate buffer saline (dPBS, Invitrogen Corporation, catalog 

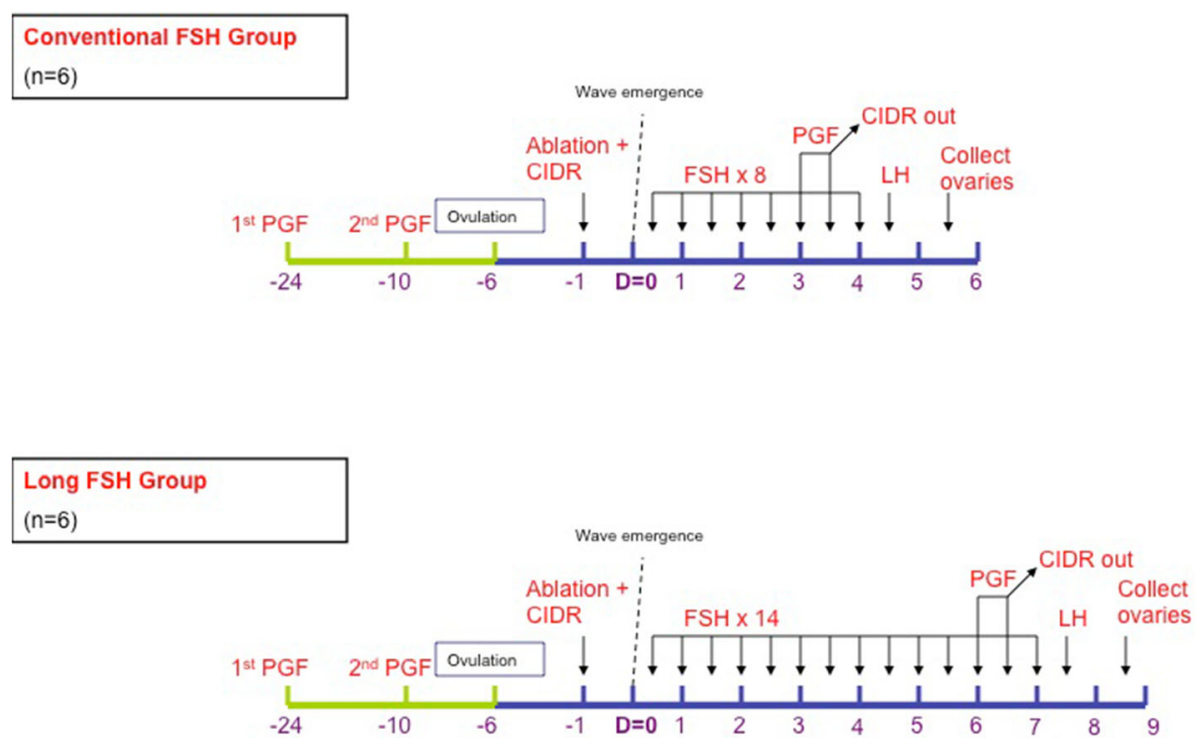

Fig. 1 Experimental protocol used to test the effect of the duration of FSH superstimulation on gene expression of granulosa cells in cattle. Transvaginal ultrasound-guided follicle ablation was performed 5 to 8 days after ovulation to synchronize wave emergence (Day 0). Beginning on Day 0, FSH was given at 12-h intervals for 4 days (conventional FSH group) or 7 days (long FSH group; $n=6$ cows per group). Cows were given $\mathrm{PGF}_{2 a}$ twice on Day 3 in the conventional FSH group or Day 6 in the long FSH group. Cows were ovariectomized $24 \mathrm{~h}$ after $\mathrm{LH}$ treatment

14,190-144, Burlington, ON, Canada). The cumulusoocyte-complex was identified by stereomicroscopy and separated from the follicular aspirate, and the remainder of the follicular aspirate and the saline flush was centrifuged to collect antral granulosa cells. The collapsed follicle was then opened in half using a scalpel blade. Identification of the 3 largest follicles was confirmed using a ruler to measure follicle diameter. The inside of the follicular wall was scraped with a microbiology culture-loop (LightLabs, catalog \# PD104, Dallas, TX, USA) to remove the mural layer of granulosa cells, which were then placed together with the antral granulosa cells. The granulosa sample (mural and antral) of each follicle was placed in an Eppendorf tube (sterile, RNAse- and DNAse-free) and plunged into liquid nitrogen and stored at $-80{ }^{\circ} \mathrm{C}$ for microarray and RT-PCR analyses. The follicular fluid was stored at $-80{ }^{\circ} \mathrm{C}$ for radioimmunoassay of progesterone and estrogen concentrations.

\section{RNA extraction and amplification}

Total RNA was extracted using the Trizol extraction method, according to the manufacturer's instructions (Invitrogen Life Technology; Thermo Fisher Scientific, Waltham, Massachusetts, USA), and resuspended in $50 \mu \mathrm{l}$ of nuclease-free water. The RNA was purified using the Arcturus PicoPure RNA Isolation and purification Kit (Catalog KIT0204, Applied Biosystem, Concord, Ontario, Canada) following the manufacturer's protocol. The purification process included DNAse treatment to remove genomic DNA, and final purified RNA was recovered in $15 \mu \mathrm{l}$ of elution buffer. RNA quality was evaluated using a Bioanalyzer-2100 (Agilent Technologies Inc., Palo Alto, CA, USA) with the RNA NanoLab Chip (Catalog \# 5067-1511; Agilent; Santa Clara, California, USA). RNA samples with an RNA integrity number (RIN) greater than 5 were used for microarray hybridizations. A linear amplification process was chosen with the intent of increasing the amount of RNA for microarray hybridizations. Equal amounts of RNA from the three largest follicles were pooled and a total of $5 \mathrm{ng}$ of RNA from the pooled sample was used for RNA amplification. Linear amplification was performed using two 6-h rounds of T7 RNA polymerase (RiboAmp HS ${ }^{\text {Plus }}$ RNA Amplification Kit; Molecular Devices, Sunnyvale, CA, USA), following manufacturer's directions, and the amount of antisense RNA (aRNA) produced was measured using NanoDrop ND-1000 (NanoDrop Technologies, Wilmington, DE, USA).

\section{Sample labeling, hybridization and microarray scanning}

For each sample, $2.5 \mu \mathrm{g}$ of aRNA were labelled using DY-547/647 (Red - CY5 and Green CY3) fluorescent dyes from ULS Labelling Kit (EA-006, Kreatech Diagnostics, Amsterdam, The Netherlands) according to the manufacturer's protocol. With the intent of removing any nonreacted ULS-label material, another round of aRNA purification was performed using the Pico-Pure RNA Isolation Kit but without DNAse I treatment. Pure labeled aRNA was eluted with $11 \mu$ l elution buffer. Labelling efficiency was measured using the NanoDrop ND-1000. A minimum of $30 \mathrm{pmol} / \mu \mathrm{g}$ of labeling signal was required to 
proceed with hybridization. A hybridization mix was prepared using: $825 \mathrm{ng}$ each of cyanine (Cy3 and Cy5) labeled amplified aRNA; Agilent and tomato spikes; nuclease free water; $10 \times$ blocking agent; and a $25 \times$ fragmentation buffer, $\mathrm{n}$ a total volume of $55 \mu \mathrm{l}$. The hybridization mix was then pipetted into the hybridization slides. Three biological replicates in each group (conventional vs long FSH) were used in the experimental design, in a dye-swap set up. Overall, 6 hybridizations were performed using a custom-built bovine oligo-microarray slide (EmbryoGENE EMBV3 manufactured by Agilent; Design ID: 028298, GEO accession \# GPL13226). The slide contained 45,220 oligo-nucleotide probes. Each gene had a duplicate oligonucleotide probe and the slide also included Agilent's positive and negative controls ( 4 arrays per slide; $44 \mathrm{~K}$ probes per array). Oligo-nucleotide sequences were taken from Oligo Microarray Consortium database (BOMC, http://www.bovineoligo.org).

Hybridization were performed (Agilent Technologies Inc., Palo Alto, CA, USA) using $2 \times$ GEx hybridization buffer HI-RPM, at $65{ }^{\circ} \mathrm{C}$ in a preheated oven for $17 \mathrm{~h}$ with a rotator speed of $10 \mathrm{rpm}$. Slides were washed with two buffers from the Gene Expression (GE) wash buffer kit (Agilent Technologies Inc., catalogue \# 5188-5327), according to manufacturer's protocol. Slides were then dipped in $100 \%$ acetonitrile for $10 \mathrm{~s}$ at room temperature and washed with stabilization and drying solution for $30 \mathrm{~s}$ at room temperature. The slides were scanned immediately using a Power scanner (Tecan US Inc., Durham, NC, USA). After image acquisition, scanned images were analyzed and quantified using Array-Pro Analyzer software (Media Cybernetics, Silver Spring, MD, USA).

\section{Data normalization and statistical analyses}

Raw signal intensity files were uploaded to the EmbryoGENE Laboratory Information Management System (LIMS) and microarray analysis platform (ELMA). Quality control was evaluated using Gydle software (http://www.gydle.com/). Signal intensity files were analyzed using FlexArray software (version 1.6.1; [29]. Simple background subtraction was done with the FlexArray software using the median foreground intensity files. If background intensity was higher than the obtained foreground intensity, negative values were replaced with 0.5 as a default. Data were normalized within and between arrays using the Loess and Quantile normalization methods, respectively. Linear Models for Microarrays (Limma) was performed to obtain differentially expressed genes in the long FSH group relative to the conventional FSH group [30, 31] using a fold-change of $\geq 2$ and a $P$-value of $\leq 0.05$ as a threshold. The false discovery rate (FDR) was determined using the Benjimeni-Hocheberg method to narrow down the true positive genes. A fold-change of $\geq 2$ and $P$ value of $\leq 0.05$ was also used for FDR. Data were deposited in NCBI Gene Expression Omnibus 226 (www.ncbi.nlm.nih.gov/geo/) with a GEO series accession number; GSE80289. A $p$-value of $\leq 0.1$ was taken as statistically significant for RT-PCR data.

\section{Functional annotation and pathway analysis}

The list of differentially expressed gene generated by Limma analysis was uploaded into Ingenuity Pathways Analysis (IPA Version: 14400082; Ingenuity Systems, www.ingenuity.com) to identify gene networks. Gene networks were used to identify likely biological functions, molecular processes and disorders, and most related pathways. IPA analyses are based on data from human and mouse studies.

\section{Real-time PCR (RT-PCR)}

Seven genes (NTS, PTGS2, PTX3, RGS2, INHBA, CCND2 and LRP8) were selected for validation using RT-PCR. Primers were designed using Primer3 (v.0.4.0, http://frodo.wi.mit.edu/primer3/), analyzed using IDT PrimerQuest tool (Oligo Analyzer, http://scitools.idtdna. com/analyzer/Applications/OligoAnalyzer/; https://www. idtdna.com/calc/analyzer), and blasted using NCBI (http://www.ncbi.nlm.nih.gov/tools/primer-blast/index.cgi? LINK_LOC=BlastHome; http://blast.ncbi.nlm.nih.gov/Blast. cgi?PROGRAM=blastn\&BLAST_PROGRAMS $=$ megaBlast \&PAGE_TYPE $=$ BlastSearch\&SHOW_DEFAULTS $=$ on \&LINK_LOC=blasthome). Selected primers met the following criteria: 20 to 24 base pairs, $55^{\circ}$ to $65{ }^{\circ} \mathrm{C}$ melting temperature, $40 \%$ to $60 \%$ of CG content, no hairpin, selfdimer or hetero-dimer formation, and specific to the gene of interest. A list of the primers selected is presented on Table 1.

Primers were tested by performing RT-PCR of cDNA from pooled granulosa cell samples. After cDNA was amplified during the PCR reaction (see below), the amplicon was run by electrophoresis on a standard $1 \%$ agarose gel to determine the size of the band. The band was cut and eluted using a QIAquick Gel Extraction kit (Cat\# 28704, Qiagen, Toronto, ON, Canada), quantified using NanoDrop ND-100 and sequenced $(3 \times$ ABI 3730xl Sanger sequencing). Primers were only used if the sequence matched the desired amplicon. The amplicon was also used for generating a standard curve. The standard curve went from $10^{-2}$ to $10^{-11} \mathrm{ng} / \mu \mathrm{l}$. Real time PCR was performed on a Stratagene Mx3005P fast thermal cycler (Applied Bioscience, Concord, Ontario, Canada) using SYBR Green master mix (Applied Bioscience). Cycle threshold (Ct) was recorded, and the expression of the gene of interest was normalized to the geometric mean of UBE2D2, EIF2B2 and SF3A1 using the Relative Expression Software Tool [32]. 
Table 1 Primers used for RT-PCR

\begin{tabular}{|c|c|c|c|}
\hline Genes & Strand & Primer sequence & Annealing temperature $\left({ }^{\circ} \mathrm{C}\right)$ \\
\hline & Forward & 5'-CATGAGATGGCAGTCAATTTGT-3' & 53.6 \\
\hline \multirow[t]{2}{*}{ EIF2B2 } & Reverse & 5'-CTTGAACATAGGAGCACAGACG-3' & 55.5 \\
\hline & Forward & 5'-TGTGTCCCTCTTGCTGAGTTT-3' & 56.4 \\
\hline \multirow[t]{2}{*}{ SF3A1 } & Reverse & 5'-ATTCCTGGTTTCACGTCTCCTA-3' & 55.5 \\
\hline & Forward & 5'-TGGACTCAGAAGTATGCGATGT-3' & 55.8 \\
\hline \multirow[t]{2}{*}{ UBE2D2 } & Reverse & 5'-CTTCTCTGCTAGGAGGCAATGT-3' & 56.6 \\
\hline & Forward & 5'-AGTGTTCCCTCTTGGAAAATGA-3' & 60 \\
\hline \multirow[t]{2}{*}{ NTS } & Reverse & 5'-TCTTCCTGAATCAACTCCCAGT-3' & 60.1 \\
\hline & Forward & 5'-AAAGCTCTAGGGGGTTCTCGT-3' & 56.3 \\
\hline \multirow[t]{2}{*}{ PTGS2 } & Reverse & 5'-TGTCAGCACATCCAGGGTAA-3' & 56 \\
\hline & Forward & 5'-GGCAGACTCACAGGCTTCAATATC-3' & 57.6 \\
\hline \multirow[t]{2}{*}{ PTX3 } & Reverse & 5'-CCTTCTCCAGTCTCCCTTTCAACT-3' & 58.2 \\
\hline & Forward & 5'-AAAGCCGCAGATCACCACAGAA-3' & 59.3 \\
\hline \multirow[t]{2}{*}{ RGS2 } & Reverse & 5'-TCCAGCTTGAGACACACCACAT-3' & 58.6 \\
\hline & Forward & 5'-CGACTTCATCGAACACATCCTTCG-3' & 57.7 \\
\hline \multirow[t]{2}{*}{ CCND2 } & Reverse & 5'-CTATTCAGCAGCACCACCTCAATC-3' & 57.8 \\
\hline & Forward & 5'-ACGCAAAGTTCTCGCAAGCTCA-3' & 59.7 \\
\hline \multirow[t]{2}{*}{ LRP8 } & Reverse & 5'-TGCC ATTTCCTCCTCAAACAGG-3' & 57.6 \\
\hline & Forward & 5'-CCAAAGGATGTACCCAACTCTC-3' & 59.8 \\
\hline INHBA & Reverse & 5'-GTCCGATGTCGTCCTCTATCTC-3' & 60.7 \\
\hline
\end{tabular}

\section{Radioimmunoassays}

Follicular fluid concentrations of estradiol and progesterone were measured by radioimmunoassay. Slaughterhouse ovaries were used to obtain a charcoal-extracted pool of fluid from follicles 3 to $8 \mathrm{~mm}$ in diameter, which was used to prepare the standards and dilute follicular fluid samples. The standard curve ranged from 5 to $1000 \mathrm{pg} / \mathrm{ml}$ for estradiol and 0.1 to $40 \mathrm{ng} / \mathrm{ml}$ for progesterone. Samples were diluted using the charcoalextracted pooled follicular fluid so that hormone concentrations fell within the limits of the standard curve and samples were assayed in duplicates. Estradiol was measured with a modified human double-antibody radioimmunoassay kit (Catalog \# KE2D1, Coat-A-Count; Siemens Healthcare Diagnostics Inc.; Mississauga, ON, Canada), using dilutions that ranged from 1:25 to 1:500. Estradiol was measured in two assays; the intra-assay coefficient of variation was $11 \%$ and the inter-assay coefficient of variation was $8 \%$. Progesterone was measured using a commercial radioimmunoassay kit (Catalog \# TKOP1, Coat-A-Count; Siemens Healthcare Diagnostics Inc.; Mississauga, ON, Canada) and all samples were diluted 1:10 and measured in a single assay. The intra-assay coefficient of variation was $6 \%$. Hormone data were compared between groups by student's t-test.

\section{Results}

A total of 1031 genes were differentially expressed in the long FSH group compared with the conventional FSH group (Fig. 2). Of the differentially expressed genes, 416 had lower expression (i.e., down regulated) and 615 had higher expression (i.e. up-regulated) in the long FSH group compared with the conventional FSH group ( $\geq 2$-fold change; $P$ value $\leq 0.05$ ), and 142 were novel transcripts. The 10 most up- and down-regulated granulosa cell gene transcripts in the long FSH group compared to the conventional FSH group are listed in Table 2.

\section{Functional classification of transcripts}

Among 1031 differentially expressed genes or isoforms, 889 were annotated for functional classification by Ingenuity Pathway analysis (IPA) software. Analysis of molecular $\left(P\right.$-value range from $4.05 \times 10^{-19}$ to $2.77 \times 10^{-04}$ ) and cellular functions (P-value range from $2.12 \times 10^{-04}$ to $2.55 \times 10^{-04}$ ) revealed that those most affected by long FSH treatment were related to cellular growth and proliferation, cell death, cellular development, and cellular function and maintenance (based on number of genes in the function). The most affected disease categories were cancer, genetic disorders, tissue development, and reproductive system disease. 


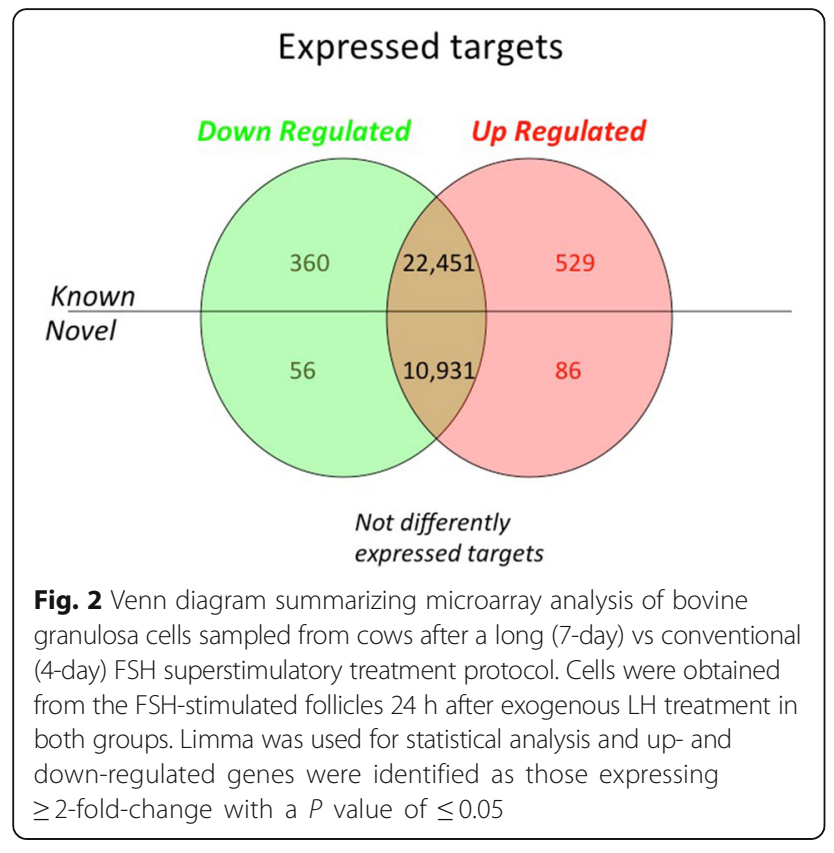

\section{Network analysis}

In the network of differentially expressed granulosa cell genes (generated with IPA software; Fig. 3), most markers were those of LH responsiveness, oocyte nuclear maturation, and oocyte competence. The genes found to be upregulated were: regulator of G-protein signalling 2 (RGS2); matrix metalloproteinase (Mmp); vanin (VNN2); guanosine triphosphate hydrolase (GTPase rho - Ras (homolog); peroxiredoxin 1 (PRDX1); prostaglandin endoperoxide synthase 2 (PTGS2); steroidogenic acute regulatory protein (STAR); mitogen activated protein kinase P38 (P38 $M A P K) ;$ mitogen activated protein kinase 14 (MAPK14); phospholipase A2, group IVA (PLA2G4A); insulin-like growth factor 2 (IGF2); selenoprotein P plasm 1 (SEPP1); periostin osteoblast specific factor (POSTN); tumor necrosis factor, alpha-induced protein 6 (TNFAIP6); pentraxin 3 (PTX3) and plasminogen activator (PLAT). The genes found to be down-regulated were: inhibin beta $B$ (INHBB); follistatin (FST); serpin peptidase inhibitor clade E member 2 (SERPINE2), vascular endothelial growth factor $C$ (VEGFC), inhibin beta $A$ (INHBA); versican (VCAN); amphiregulin (AREG); low-density lipoprotein receptor related protein 8 (LRP8); cytochrome P450 family 19 subfamily A polypeptide 1 (CYP19A1); cyclin D2 (CCND2); cyclin dependent kinase 1 (CDK1); progesterone receptor $(P G R)$.

\section{Real-time PCR validation}

Based on microarray data and functional analysis, 7 genes (NTS, PTGS2, PTX3, RGS2, INHBA, CCND2 and LRP8) were selected for validation with RT-PCR. The selection of the genes for validation was based on the role they played in the results, as those genes were involved in the hypotheses being generated by the microarray analysis and not necessarily the genes with the most elevated fold change variations. The selected genes were quantified in three independent biological replicates

Table 2 The top 10 up- and down-regulated genes in bovine granulosa cells sampled from cows after a long (7-day) vs conventional (4-day) FSH superstimulatory treatment protocol (3 largest follicles pooled)

\begin{tabular}{llll}
\hline Genes & Description & $P$ value & \\
\hline Up-Regulated & & & Fold change \\
PTX3 & Pentraxin 3 & $3.7 \times 10^{-13}$ & 5.904 \\
VNN3 & Vanin 3 & $3.3 \times 10^{-11}$ & 5.281 \\
POSTN & Pcriostin, Osteoblast specific factor & $1.4 \times 10^{-07}$ & 4.241 \\
PTGS2 & Prostaglandin cndopcroxidc synthase 2 & $1.5 \times 10^{-07}$ & 4.182 \\
GRIA3 & Glutamate receptor, ionotropic, AMPA3 & $8.4 \times 10^{-07}$ & 4.175 \\
RGS2 & Regulator of G protein signaling 2 & $2.9 \times 10^{-06}$ & 3.702 \\
GFRA1 & GDNF family receptor alpha I & $7.5 \times 10^{-05}$ & 3.679 \\
PLA2G4A & Phospholipase A2 group Iva (cytosolic, Ca dependent) & $4.4 \times 10^{-07}$ & 3.605 \\
CRISPLD2 & Cysteine rich secretory protein LCCL domain containing 2 & $2.9 \times 10^{-05}$ & 3.604 \\
GIMAP4 & GTPase IMAP family member 4 & $9.0 \times 10^{-12}$ & 3.545 \\
Down-Regulated & & & -3.978 \\
INHBA & Inhibin beta A & $2.0 \times 10^{-07}$ & -3.784 \\
LRP8 & Low density lipoprotein receptor-related protein 8 & $1.4 \times 10^{-07}$ & -3.437 \\
CCND2 & Cyclin D2 & $5.9 \times 10^{-09}$ & -3.055 \\
SRGN & Serglycin & $1.2 \times 10^{-05}$ & -3.055 \\
BEX2 & Brain expressed X-linkcd 2 & $3.3 \times 10^{-07}$ & -3.031 \\
INHBB & Inhibin beta B & $2.9 \times 10^{-07}$ & \\
\hline
\end{tabular}




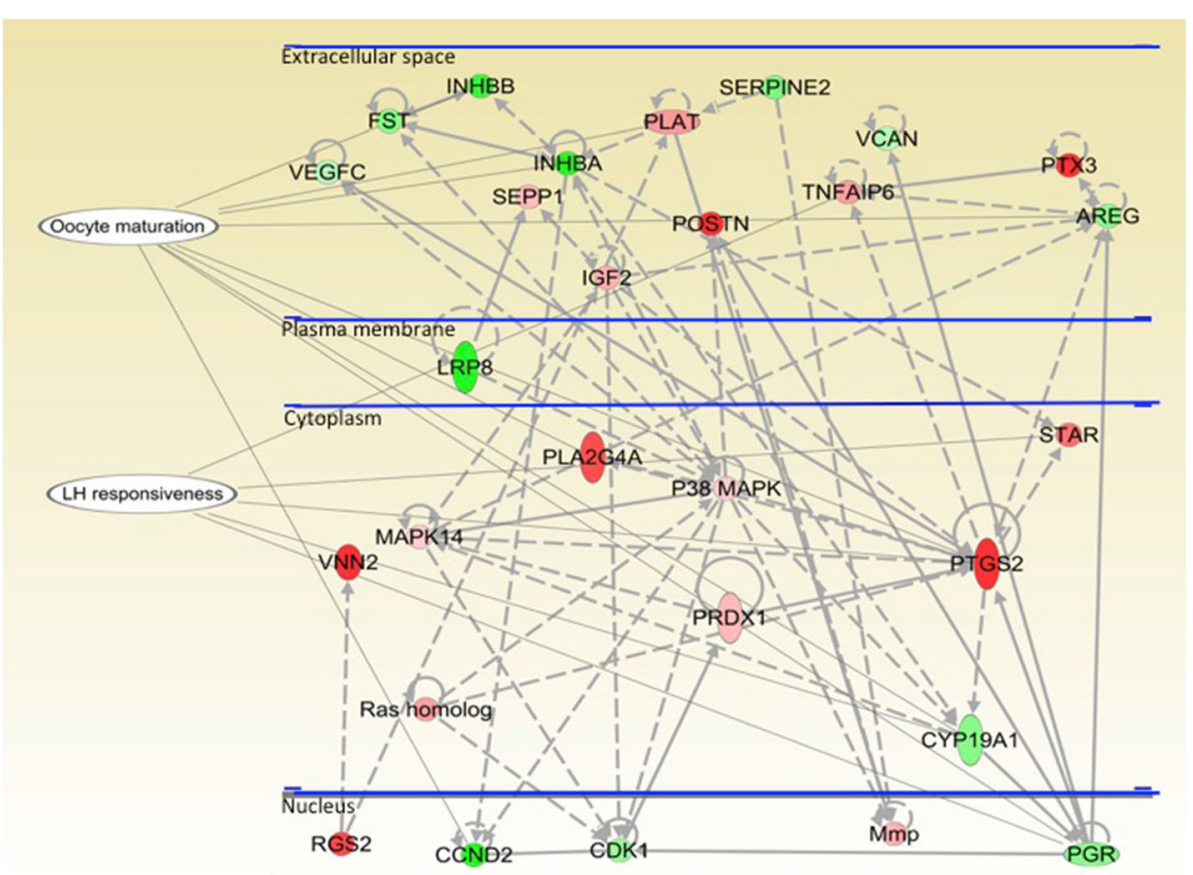

Fig. 3 Network of up-(red) or down-(green) regulated genes and their interactions in granulosa cells after long duration of growing phase of dominant follicles (7-day FSH) compared to conventional 4-day FSH treatment (reference group). Cells were obtained from the FSH-stimulated follicles $24 \mathrm{~h}$ after exogenous LH treatment in both groups. Genes involved in this network are markers of follicle LH responsiveness, oocyte nuclear maturation and oocyte competence. The differences in color intensity of molecules show the degree of up or down regulation. Network generated by Ingenuity Pathway Analysis software

(samples coming from three different animals) from the long- and conventional-FSH groups. The expression of 4 of 7 genes was statistically different between groups using RT-PCR (NTS, PTGS2, PTX3 and RGS2) with a $90 \%$ confidence interval ( $P$ value $\leq 0.1$ ), indicating a positive validation (Fig. 4). Although expression of the 3 remaining genes was not statistically different between groups (INHBA, CCND2, and LRP8), numerical differences followed the same trend as that of the microarray dataset. Since we have used a FDR filter, the chances of having false positive genes identified as differently expressed is lower although not impossible. The use of only 3 replicates was justified by the difficulties to generate more materials from such experiments. It is clear that, using more replicates may better support the PCR vs Array results where statistical power is increased by the measurement of 40,000 targets at the same time. The IPA analysis is especially made for such context and the analysis of tens of genes at the same time to assess a function or a pathway is more powerful in somatic tissues than individual PCR changes we can measure. This is the value of whole genome analysis.

\section{Follicular fluid analysis}

Lower concentrations of estradiol were detected in the follicular fluid in the long FSH group than in the

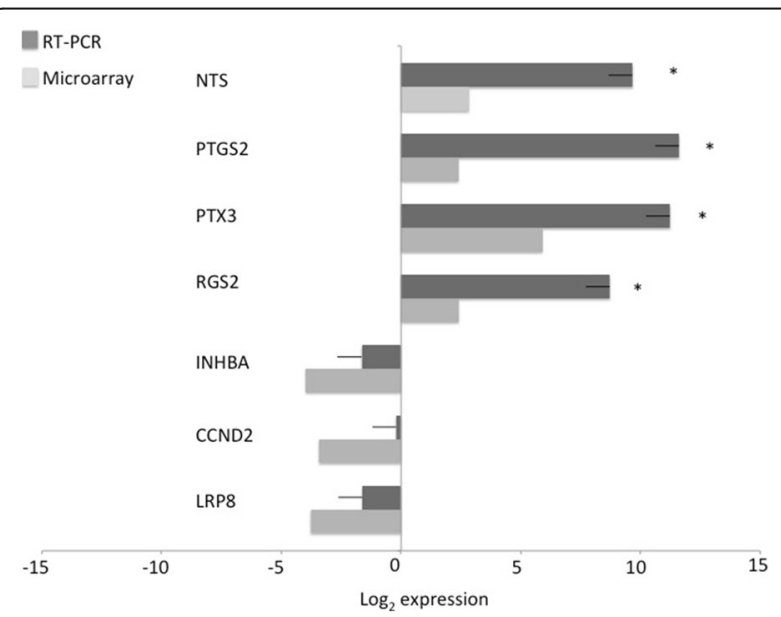

Fig. 4 Quantification ( $\log _{2}$ of fold-change; mean \pm SEM) of the mRNA profiles in granulosa cells after a Long (7-day) compared to conventional (4-day, reference group) FSH treatment. Cells were obtained from the FSH-stimulated follicles $24 \mathrm{~h}$ after exogenous $\mathrm{LH}$ treatment in both groups. Bars extending to the right and left of zero represent up- and down-regulated genes, respectively, in the Long FSH group. RT-PCR data analysis was performed using REST 2009 program. Light grey bars represent expression of transcript in microarray experiment while dark grey bars represent expression of the same transcript obtained by RT-PCR. Asterisk (*) by the side of a bar represent statistical difference $(P<0.1)$ between long FSH in relation to the conventional FSH in RT-PCR experiments 
conventional FSH group $(27.1 \pm 7.6 \mathrm{vs} 153.8 \pm 32.7 \mathrm{ng} / \mathrm{ml}$, mean \pm SEM, $P=0.001$ ). Conversely, follicular fluid progesterone concentrations were higher in the long $\mathrm{FSH}$ group than in the conventional FSH group $(212.9 \pm 24.5$ vs $99.9 \pm 19.7 \mathrm{ng} / \mathrm{ml}, \mathrm{P}=0.001)$. Accordingly, the estradiol: progesterone ratio was lower in the follicular fluid of the long- vs conventional-FSH group $(0.13 \pm 0.04$ vs $3.5 \pm 0.8$, $P=0.0006)$.

\section{Discussion}

The microarray technique provides a global analysis of the transcriptome of a tissue and is a hypothesisgenerating tool. Microarray-based comparisons of mRNA transcripts of granulosa cells after 7-day FSH treatment versus the conventional 4-day treatment provide rationale for two postulates: Extending the superstimulation protocol by 3 days 1 ) activated molecular mechanisms of LH-responsiveness, and 2) increased expression of markers of oocyte competence in the granulosa cells. Therefore, follicles after long FSH were at optimal stage of differentiation to respond to an exogenous LH surge compared to follicles from the conventional FSH group. Taken together with our studies on superstimulation, oocyte maturation, ovulatory potential and embryonic development $[16,17,25]$, results of the present study support the notion that 7-day superstimulatory treatment results in healthier follicles and more competent oocytes than the conventional 4-day protocol. Further, our results provide insights into the molecular mechanism for observed biological effects.

The LH surge is an important event that triggers resumption of meiosis in the oocyte and culminates in ovulation. At the molecular level, the LH surge initiates progressive changes in granulosa and theca cell functions including intercellular communications, tissue remodelling, steroidogenic and prostaglandin pathways, and mitosis. The specific genes influenced by the LH surge have been referred to as "markers of LH responsiveness" [33]. In our study, VNN, POSTN, PLA2G4A, GTPase, Cysteine (Fig. 3) were up-regulated in the long FSH group; these genes have been described as markers of the LH surge [33, 34]. Conversely, most of the downregulated genes (CYP19A1, LRP8, CJA1, INHBA and SERPINE2) are those whose expression increase with dominant follicle growth till the time of LH surge (i.e., markers of pre LH surge) and are normally downregulated after LH surge [35]. It is interesting to note that animals were ovariectomized $24 \mathrm{~h}$ after $\mathrm{LH}$ treatment; therefore, follicles in the long FSH group responded better to exogenous $\mathrm{LH}$ than those in the conventional FSH group. Although this is a really interesting finding, it may be too early to speculate a specific role of for some of those genes on granulosa cell maturation.
Pentraxin 3 (PTX3) was the most up-regulated gene in the study. Previous studies document that its expression increased after the LH surge [36]. PTX3 is also considered a marker of fertility [37, 38], suggesting that long FSH treatment may be associated with a more competent oocyte. In this regard, the effect of similar superstimulation protocols (long vs conventional FSH) on oocyte competence after in vitro fertilization were compared in a previous study [25] and although no morphologic differences were found between groups, long FSH treatment resulted in the production of 2.5 times more transferable embryos than the conventional FSH group [25]. In addition to the effect of LH on pentraxin 3 expression, when endoplasmic reticulum stress was artificially activated in cumulus-oocyte complexes, the secretion of pentraxin-3 was significantly reduced; in vitro fertilization rate was reduced, and embryos were slower to develop [37]. Perhaps a greater expression of pentra$x i n$ is the molecular explanation for greater embryonic development after a long FSH protocol in our earlier studies [25].

Prostaglandin biosynthesis in granulosa cells depends on the initial release of arachidonic acid from membrane phospholipids, and its production is increased by the $\mathrm{LH}$ surge [39]. Two of the up-regulated genes in the long FSH group were related to production of prostaglandin, PLA2G4A and PTGS2. Expression of PLA2G4A is responsible for LH-stimulated mobilization of arachidonic acid [40] via the adenyl cyclase/cAMP pathway [39], and expression of PTGS2 (or COX 2) converts arachidonic acid to prostaglandin [41]. Inhibited expression of PTGS2 has been associated with disturbances in ovulation [42-45]. Further, PTGS2 was highly expressed in bovine preovulatory follicles after the endogenous $\mathrm{LH}$ surge [46], and has been implicated in oocyte maturation by differentially influencing multiple signaling pathways such as cAMP-dependent protein kinase, MAPK, NF-kappaB and phosphatidylinositol 3-kinase/AKT pathways [47]. Evidence of up-regulation of both enzymes (PLA2G4A and PTGS2) in the long FSH group in the present study is consistent with the concept that such treatment increased follicle maturity and ability to ovulate in response to $\mathrm{LH}$ than those after conventional FSH treatment. This concept is supported by the detection of a greater proportion of oocytes in metaphase II after a 7-day FSH protocol that a shorter conventional protocol [17].

Genes encoding the low-density lipoprotein receptorrelated protein 8 (LRP8), cyclin D2 (CCND2) and cytochrome $P 450$ family51 subfamily A polypeptide1 (CYP51A1) were all down-regulated in the long FSH group in the present study, and have all been shown to be down-regulated after the LH surge [36, 48, 49]. Cyclin D2 functions as a regulatory subunit of cyclin dependent kinase 4 or 6 (CDK 4 or 6 ) whose activity is required for 
cell cycle G1/S transition. Cyclin D2 mRNA is present in granulosa cells of growing follicles, and its expression was induced by FSH but rapidly inhibited by LH $[50,51]$. When ovulatory doses of human LH were administered to rats, cyclin D2 mRNA and protein were rapidly decreased and were undetectable within $4 \mathrm{~h}$. The presence of CCND2 in human cumulus cells at the time of oocyte retrieval is also suggested to be a marker for lower embryo development and consequently low fertility [52]. Our finding that the cyclin $D 2$ gene was expressed at a higher level after conventional FSH treatment (i.e. down-regulated in long FSH group) demonstrate that extending the superstimulation protocol by 3 days may be beneficial to both follicular and oocyte health.

In an earlier study [24], we found that follicles superstimulated with a conventional 4-day FSH-protocol lagged behind in maturation and differentiation compared to the single (unstimulated) dominant follicle; i.e., most of the up-regulated genes were markers of the follicular growth phase [23]. In the present study, an additional 3 days of FSH stimulation resulted downregulation of the same genes that had been up-regulated in the previous study using the shorter conventional FSH treatment, suggesting that the extra 3 days of gonadotropin support allowed follicles to reach a more mature, ovulation-ready state.

In cattle, intra-follicular aromatase activity increased during follicular growth [53] but decreased markedly by 24-h after LH $[54,55]$. In the present study, the long FSH group had lower intrafollicular concentrations of estradiol and higher concentrations of progesterone than the shorter conventional FSH group. Although direct comparison between the 7-day FSH protocol and a single (unstimulated) dominant follicle was not possible in the present study, follicles in long FSH group were still estrogen active and not fully atretic, based on indirect comparison with follicular fluid concentrations of estradiol and progesterone in subordinate follicles [28]. Few apoptotic genes were up-regulated in the long FSH group in the present study; e.g., Caspase 8. Sequential activation of caspases plays a central role in cell apoptosis. Similar to the long FSH group, down-regulated genes in aged, persistent follicles included amino acid transporter A2, aurora kinase family ( $A$ and $B)$, fructose $-1,6$ bisphosphatase and malate dehydrogenase [56, 57]. Likewise, glutathione S-transferase isoform was upregulated in both persistent follicles [56] and in the long FSH group in the present study. Early stages of follicle atresia have been associated with improved developmental capacity of oocytes [58-61]. Perhaps, changes analogous to the static or early regressing phases of a dominant follicle occurred in the long FSH group whereas follicles in the conventional FSH treatment group were still in the less differentiated growing phase.

\section{Conclusion}

In conclusion, the extended protocol activates molecular mechanisms of LH-responsiveness and increases expression of markers of oocyte competence in the granulosa cells. Therefore, extending FSH treatment by 3 days allowed the granulosa cells to differentiate and proper respond to $\mathrm{LH}$ stimulus. These results support the notion that 7-day superstimulatory treatment is an alternative to obtain healthier follicles and oocytes.

\section{Abbreviations \\ aRNA: Anti-sense RNA; DNA: Deoxyribonucleic acid; ELMA: EmbryoGENE LIMS and microarray analysis; FDR: False discovery rate; FSH: Follicle stimulation hormone; IPA: Ingenuity pathways analysis; LH: Luteinizing hormone; LIMMA: Linear models for microarray analysis; LIMS: Laboratory information management system; PGF 2 : Prostaglandin F2-alpha; RNA: Ribonucleic acid; RT-PCR: Reverse transcription polymerase chain reaction}

\section{Acknowledgements \\ Authors thank EmbryoGene Network and the Natural Sciences and Engineering Research Council of Canada for funding. Authors would like to express gratitude to Isabelle Dufort for her guidance during most of the laboratory procedures and to the staff at the University of Saskatchewan Goodale Cattle Farm for care and maintenance of cows.}

\section{Funding \\ This project was funded by the EmbryoGene Network and the Natural Sciences and Engineering Research Council of Canada.}

\section{Availability of data and materials}

Data were deposited in NCBI Gene Expression Omnibus 226 (www.ncbi.nlm.nih.gov/geo/) with a GEO series accession number; GSE80289.

\section{Authors' contributions \\ The project was designed by JS, GPA, and MAS. Experiments were performed by FCFD and MIRK. The manuscript was written by FCFD and revised by all authors. All authors approved the final version of this paper.}

Ethics approval and consent to participate

Procedures were conducted in accordance with the guidelines of the Canadian Council on Animal Care and were approved by University of Saskatchewan Protocol Review Committee.

\section{Competing interests}

The authors declare that they have no competing interests.

\section{Publisher's Note}

Springer Nature remains neutral with regard to jurisdictional claims in published maps and institutional affiliations.

\section{Author details}

'Department of Veterinary Biomedical Sciences, Western College of Veterinary Medicine, University of Saskatchewan, 52 Campus Drive, Saskatoon, SK S7N 5B4, Canada. ${ }^{2}$ Departement des Sciences Animales, Centre de Recherche en Biologie de la Reproduction, Universite' Laval, Sainte-Foy, Quebec G1K 7P4, Canada. ${ }^{3}$ Department of Theriogenology, University of Veterinary and Animal Sciences, Lahore 54000, Pakistan.

Received: 5 January 2017 Accepted: 3 April 2018

Published online: 16 April 2018

\section{References}

1. Adams GP, Matteri RL, Kastelic JP, Ko JC, Ginther OJ. Association between surges of follicle-stimulating hormone and the emergence of follicular waves in heifers. J Reprod Fertil. 1992;94(1):177-88. 
2. Ginther OJ, Kastelic JP, Knopf L. Compositions and characteristics of follicular waves during the bovine estrous cycle. Anim Reprod Sci. 1989;20:187-200.

3. Ginther OJ, Knopf L, Kastelic JP. Temporal associations among ovarian events in cattle during oestrous cycles with two and three follicular waves. J Reprod Fertil. 1989;87(1):223-30.

4. Jaiswal RS, Singh J, Marshall L, Adams GP. Repeatability of 2-wave and 3-wave patterns of ovarian follicular development during the bovine estrous cycle. Theriogenology. 2009;72(1):81-90.

5. Adams GP, Matteri RL, Ginther OJ. Effect of progesterone on ovarian follicles, emergence of follicular waves and circulating follicle-stimulating hormone in heifers. J Reprod Fertil. 1992;96(2):627-40.

6. Savio JD, Thatcher WW, Morris GR, Entwistle K, Drost M, Mattiacci MR. Effects of induction of low plasma progesterone concentrations with a progesteronereleasing intravaginal device on follicular turnover and fertility in cattle. J Reprod Fertil. 1993;98(1):77-84.

7. Mihm M, Baguisi A, Boland MP, Roche JF. Association between the duration of dominance of the ovulatory follicle and pregnancy rate in beef heifers. J Reprod Fertil. 1994;102(1):123-30.

8. Lee CN, Cook DL, Parfet JR, Smith CA, Youngquist RS, Garverick HA. Induction of persistent ovarian follicular structures following administration of progesterone near the onset of estrus in dairy cattle. J Dairy Sci. 1988;71(12):3505-8.

9. Noble KM, Tebble JE, Harvey D, Dobson H. Ultrasonography and hormone profiles of persistent ovarian follicles (cysts) induced with low doses of progesterone in cattle. J Reprod Fertil. 2000;120(2):361-6.

10. Ahmad N, Townsend EC, Dailey RA, Inskeep EK. Relationships of hormonal patterns and fertility to occurrence of two or three waves of ovarian follicles, before and after breeding, in beef cows and heifers. Anim Reprod Sci. 1997;49(1):13-28.

11. Bleach EC, Glencross RG, Knight PG. Association between ovarian follicle development and pregnancy rates in dairy cows undergoing spontaneous oestrous cycles. Reproduction. 2004;127(5):621-9.

12. Knopf L, Kastelic JP, Schallenberger E, Ginther OJ. Ovarian follicular dynamics in heifers: test of two-wave hypothesis by ultrasonically monitoring individual follicles. Domest Anim Endocrinol. 1989;6(2):111-9.

13. Townson DH, Tsang PC, Butler WR, Frajblat M, Griel LC Jr, Johnson CJ, Milvae RA, Niksic GM, Pate JL. Relationship of fertility to ovarian follicular waves before breeding in dairy cows. J Anim Sci. 2002;80(4):1053-8.

14. Dias FC, Mapletoft RJ, Kastelic JP, Adams GP, Colazo MG, Stover BC, Dochi $\mathrm{O}$, Singh $\mathrm{J}$. Effect of length of progesterone exposure during ovulatory wave development on pregnancy rate. Theriogenology. 2012;77(2):437-44.

15. Dias FC, Costa E, Adams GP, Mapletoft RJ, Kastelic JP, Dochi O, Singh J. Effect of duration of growing phase of ovulatory follicles on oocyte competence in superstimulated cattle. Reprod Fertil Dev. 2012;25(3):523-30.

16. Garcia Guerra A, Tribulo A, Yapura J, Singh J, Mapletoft RJ. Effect of length of superstimulatory treatment protocol on ovarian response and number of transferable embryos in beef cattle. Theriogenology. 2012;78(2):353-60.

17. Dadarwal D, Honparkhe M, Dias FC, Alce T, Lessard C, Singh J. Effect of superstimulation protocols on nuclear maturation and distribution of lipid droplets in bovine oocytes. Reprod Fertil Dev. 2015;27(8):1137-46.

18. Carabatsos MJ, Sellitto C, Goodenough DA, Albertini DF. Oocyte-granulosa cell heterologous gap junctions are required for the coordination of nuclear and cytoplasmic meiotic competence. Dev Biol. 2000;226(2):167-79.

19. Eppig JJ. Analysis of mouse oogenesis in vitro. Oocyte isolation and the utilization of exogenous energy sources by growing oocytes. J Exp Zool. 1976;198(3):375-82.

20. Haghighat N, Van Winkle LJ. Developmental change in follicular cellenhanced amino acid uptake into mouse oocytes that depends on intact gap junctions and transport system Gly. J Exp Zool. 1990;253(1):71-82.

21. Thomas FH, Vanderhyden BC. Oocyte-granulosa cell interactions during mouse follicular development: regulation of kit ligand expression and its role in oocyte growth. Reprod Biol Endocrinol. 2006;4:19.

22. De La Fuente R, Eppig JJ. Transcriptional activity of the mouse oocyte genome: companion granulosa cells modulate transcription and chromatin remodeling. Dev Biol. 2001;229(1):224-36.

23. Dias FC, Khan Ml, Adams GP, Sirard MA, Singh J. Granulosa cell function and oocyte competence: super-follicles, super-moms and super-stimulation in cattle. Anim Reprod Sci. 2014;149(1-2):80-9.

24. Dias FC, Khan MI, Sirard MA, Adams GP, Singh J. Differential gene expression of granulosa cells after ovarian superstimulation in beef cattle. Reproduction. 2013;146(2):181-91.
25. Dias FC, Dadarwal D, Adams GP, Mrigank H, Mapletoft RJ, Singh J. Length of the follicular growing phase and oocyte competence in beef heifers. Theriogenology. 2013;79(8):1177-83.

26. Garcia Guerra A, Tribulo A, Yapura J, Adams GP, Singh J, Mapletoft RJ. Lengthened superstimulatory treatment in cattle: evidence for rescue of follicles within a wave rather than continuous recruitment of new follicles. Theriogenology. 2015;84(3):467-76.

27. Bergfelt DR, Lightfoot KC, Adams GP. Ovarian synchronization following ultrasound-guided follicular ablation in heifers. Theriogenology. 1994;42:895-907.

28. Singh J, Pierson RA, Adams GP. Ultrasound image attributes of bovine ovarian follicles and endocrine and functional correlates. J Reprod Fertil. 1998;112(1):19-29.

29. Blazejczyk M, Miron M, Nadon R. FlexArray: a statistical data analysis software for gene expression microarrays. In. Montreal, Canada: Genome Quebec; 2007.

30. Smyth GK. Limma: linear models for microarray data. In: Gentleman R, Carey V, Huber W, irizarry R, Springer DS, editors. Bioinformatics and computational biology solutions using $\mathrm{R}$ and Bioconductor. New York: Springer; 2005. p. 473.

31. Smyth GK. Linear models and empirical bayes methods for assessing differential expression in microarray experiments. Stat Appl Genet Mol Biol. 2004;3(1):3.

32. Pfaffl MW, Horgan GW, Dempfle L. Relative expression software tool (REST) for group-wise comparison and statistical analysis of relative expression results in real-time PCR. Nucleic Acids Res. 2002;30(9):e36.

33. Gilbert I, Robert C, Vigneault C, Blondin P, Sirard MA. Impact of the LH surge on granulosa cell transcript levels as markers of oocyte developmental competence in cattle. Reproduction. 2012;143(6):735-47.

34. Gilbert I, Robert C, Dieleman S, Blondin P, Sirard MA. Transcriptional effect of the LH surge in bovine granulosa cells during the peri-ovulation period. Reproduction. 2011;141(2):193-205.

35. Ndiaye K, Fayad T, Silversides DW, Sirois J, Lussier JG. Identification of downregulated messenger RNAs in bovine granulosa cells of dominant follicles following stimulation with human chorionic gonadotropin. Biol Reprod. 2005;73(2):324-33.

36. Agca C, Ries JE, Kolath SJ, Kim JH, Forrester LJ, Antoniou E, Whitworth KM, Mathialagan N, Springer GK, Prather RS, et al. Luteinization of porcine preovulatory follicles leads to systematic changes in follicular gene expression. Reproduction. 2006;132(1):133-45.

37. Wu LL, Russell DL, Norman RJ, Robker RL. Endoplasmic reticulum (ER) stress in cumulus-oocyte complexes impairs pentraxin-3 secretion, mitochondrial membrane potential (DeltaPsi m), and embryo development. Mol Endocrinol. 2012;26(4):562-73.

38. Zhang X, Jafari N, Barnes RB, Confino E, Milad M, Kazer RR. Studies of gene expression in human cumulus cells indicate pentraxin 3 as a possible marker for oocyte quality. Fertil Steril. 2005;83(Suppl 1):1169-79.

39. Diouf MN, Sayasith K, Lefebvre R, Silversides DW, Sirois J, Lussier JG. Expression of phospholipase A2 group IVA (PLA2G4A) is upregulated by human chorionic gonadotropin in bovine granulosa cells of ovulatory follicles. Biol Reprod. 2006;74(6):1096-103.

40. Duffy DM, Seachord CL, Dozier BL. An ovulatory gonadotropin stimulus increases cytosolic phospholipase A2 expression and activity in granulosa cells of primate periovulatory follicles. J Clin Endocrinol Metab. 2005;90(10):5858-65.

41. Shimada M, Hernandez-Gonzalez I, Gonzalez-Robayna I, Richards JS. Paracrine and autocrine regulation of epidermal growth factor-like factors in cumulus oocyte complexes and granulosa cells: key roles for prostaglandin synthase 2 and progesterone receptor. Mol Endocrinol. 2006;20(6):1352-65.

42. Pall M, Friden BE, Brannstrom M. Induction of delayed follicular rupture in the human by the selective COX-2 inhibitor rofecoxib: a randomized double-blind study. Hum Reprod. 2001;16(7):1323-8.

43. Hester KE, Harper MJ, Duffy DM. Oral administration of the cyclooxygenase2 (COX-2) inhibitor meloxicam blocks ovulation in non-human primates when administered to simulate emergency contraception. Hum Reprod. 2010;25(2):360-7.

44. Bridges PJ, Komar CM, Fortune JE. Gonadotropin-induced expression of messenger ribonucleic acid for cyclooxygenase-2 and production of prostaglandins $\mathrm{E}$ and F2alpha in bovine preovulatory follicles are regulated by the progesterone receptor. Endocrinology. 2006;147(10):4713-22.

45. Davis BJ, Lennard DE, Lee CA, Tiano HF, Morham SG, Wetsel WC, Langenbach R. Anovulation in cyclooxygenase-2-deficient mice is restored by prostaglandin E2 and interleukin-1beta. Endocrinology. 1999;140(6):2685-95 
46. Liu J, Carriere PD, Dore $M$, Sirois J. Prostaglandin G/H synthase-2 is expressed in bovine preovulatory follicles after the endogenous surge of luteinizing hormone. Biol Reprod. 1997;57(6):1524-31.

47. Takahashi T, Morrow JD, Wang H, Dey SK. Cyclooxygenase-2-derived prostaglandin $\mathrm{E}(2)$ directs oocyte maturation by differentially influencing multiple signaling pathways. J Biol Chem. 2006;281(48):37117-29.

48. Fayad T, Lefebvre R, Nimpf J, Silversides DW, Lussier JG. Low-density lipoprotein receptor-related protein 8 (LRP8) is upregulated in granulosa cells of bovine dominant follicle: molecular characterization and spatio-temporal expression studies. Biol Reprod. 2007;76(3):466-75.

49. Vaknin KM, Lazar S, Popliker M, Tsafriri A. Role of meiosis-activating sterols in rat oocyte maturation: effects of specific inhibitors and changes in the expression of lanosterol 14alpha-demethylase during the preovulatory period. Biol Reprod. 2001;64(1):299-309.

50. Robker RL, Richards JS. Hormone-induced proliferation and differentiation of granulosa cells: a coordinated balance of the cell cycle regulators cyclin D2 and p27Kip1. Mol Endocrinol. 1998;12(7):924-40.

51. Robker RL, Richards JS. Hormonal control of the cell cycle in ovarian cells: proliferation versus differentiation. Biol Reprod. 1998;59(3):476-82.

52. van Montfoort AP, Geraedts JP, Dumoulin JC, Stassen AP, Evers JL, Ayoubi TA Differential gene expression in cumulus cells as a prognostic indicator of embryo viability: a microarray analysis. Mol Hum Reprod. 2008;14(3):157-68.

53. Carriere PD, Harvey D, Cooke GM. The role of pregnenolone-metabolizing enzymes in the regulation of oestradiol biosynthesis during development of the first wave dominant follicle in the cow. J Endocrinol. 1996;149(2):233-42.

54. Dieleman SJ, Bevers MM, Poortman J, van Tol HT. Steroid and pituitary hormone concentrations in the fluid of preovulatory bovine follicles relative to the peak of LH in the peripheral blood. J Reprod Fertil. 1983;69(2):641-9.

55. Dieleman SJ, Kruip TA, Fontijne P, de Jong WH, van der Weyden GC. Changes in oestradiol, progesterone and testosterone concentrations in follicular fluid and in the micromorphology of preovulatory bovine follicles relative to the peak of luteinizing hormone. J Endocrinol. 1983;97(1):31-42.

56. Lingenfelter BM, Dailey RA, Inskeep EK, Vernon MW, Poole DH, Rhinehart JD, Yao J. Microarray analysis of gene expression in granulosal cells from persistent follicles in cattle. Anim Reprod Sci. 2008;104(2-4):405-13.

57. Lingenfelter BM, Dailey RA, Inskeep EK, Vernon MW, Poole DH, Rhinehart JD, Yao J. Changes of maternal transcripts in oocytes from persistent follicles in cattle. Mol Reprod Dev. 2007;74(3):265-72.

58. Blondin P, Sirard MA. Oocyte and follicular morphology as determining characteristics for developmental competence in bovine oocytes. Mol Reprod Dev. 1995;41(1):54-62.

59. Blondin P, Coenen K, Guilbault LA, Sirard MA. In vitro production of bovine embryos: developmental competence is acquired before maturation. Theriogenology. 1997;47(5):1061-75.

60. Salamone DF, Adams GP, Mapletoft RJ. Changes in the cumulus-oocyte complex of subordinate follicles relative to follicular wave status in cattle. Theriogenology. 1999;52(4):549-61.

61. Barnes FL, Sirard MA. Oocyte maturation. Semin Reprod Med. 2000;18(2):123-31.

\section{Ready to submit your research? Choose BMC and benefit from:}

- fast, convenient online submission

- thorough peer review by experienced researchers in your field

- rapid publication on acceptance

- support for research data, including large and complex data types

- gold Open Access which fosters wider collaboration and increased citations

- maximum visibility for your research: over $100 \mathrm{M}$ website views per year

At BMC, research is always in progress.

Learn more biomedcentral.com/submissions 